\title{
Kadercilik Eğilimi İle Özyeterlik İnancı ve Savunma Mekanizmaları Arasındaki
} İlişkinin İncelenmesi

\begin{abstract}
Alim KAYA ${ }^{1}$
Binaz BOZKUR ${ }^{2}$

Geliş Tarihi: 2016-09-27

Kabul Tarihi: 2017-02-01

\section{Öz}

$\mathrm{Bu}$ çalışmanın amacı kadercilik eğiliminin özyeterlik inancı ve savunma mekanizmalarını yordayıp yordamadığını ve kadercilik eğiliminin cinsiyet değişkenine göre farklılaşıp farklılaşmadığını incelemektir. Araştırmanın çalışma grubunu 428 üniversite öğrencisi (277 kadın, 171 erkek) oluşturmaktadır. Verilerin analizinde Pearson Momentler Çarpım Korelasyon Katsayısı, bağımsız örneklemler için t testi ve aşamalı çoklu doğrusal regresyon analizi tekniklerinden yararlanılmıştır. Yapılan analizler sonucunda kadercilik eğilimi ve kadercilik eğiliminin alt boyutları ile özyeterlik inancı ve olgun (matür) savunma biçimleri arasında negatif ve anlamlı bir ilişki olduğu gözlenmiştir. Kadercilik eğilimi ile olgun olmayan (immatür) savunma biçimleri ve nevrotik savunma biçimleri arasında ise pozitif ve anlamlı bir ilişki olduğu saptanmıştır. Yapılan aşamalı çoklu doğrusal regresyon analizinin sonucunda kadercilik eğiliminin kişisel kontrol eksikliği ve şans alt boyutlarının özyeterlik inancının anlamlı yordayıcıları olduğu sonucuna ulaşılmıştır. Kadercilik eğiliminin kişisel kontrol eksikliği altboyutunun olgun savunmaların, şans ve batıl inanç alt boyutlarının olgun olmayan savunma biçimlerinin, önceden belirlenmişlik ve kişisel kontrol eksikliğinin ise nevrotik savunma biçimlerinin anlamlı yordayıcıları olduğu gözlenmiştir. Yapılan analizlerde kadınların erkeklere oranla daha fazla kaderci eğilime sahip oldukları sonucuna ulaşılmıştır. Sonuç olarak kadercilik eğiliminin genel özyeterlik inancı ve savunma mekanizmalarıyla ilişkili olması ve bu değişkenleri yordaması, ayrıca kadercilik eğiliminin cinsiyete göre farklılaşması bireysel ve toplumsal faktörlerin karşılıklı olarak birbirini etkilediğini göstermesi açısından önemlidir.
\end{abstract}

Anahtar kelimeler: Kadercilik eğilimi, özyeterlik inancı, savuma mekanizmaları

\footnotetext{
${ }^{1}$ Prof. Dr., Mersin Üniversitesi, Eğitim Fakültesi, Eğitim Bilimleri Anabilim dalı, Rehberlik ve Psikolojik Danışma Bölümü, alim.kaya@mersin.edu.tr

2 Araş.Gör., Mersin Üniversitesi, Eğitim Fakültesi, Eğitim Bilimleri Anabilim dalı, Rehberlik ve Psikolojik Danışma Bölümü, binaz.bozkur@mersin.edu.tr
} 


\title{
Investigating the Relationship Between Tendency of Fatalism, Self-Efficacy and Defense Styles
}

Submitted by 2016-09-27

Accepted by 2017-02-01

\begin{abstract}
The study is a descriptive research and is based on the relational model. The aim of the present study was to investigate the relationship between tendency of fatalism, self-efficacy and defense styles. It also investigated whether the dimensions of tendency of fatalism predicts self-efficacy and defense styles or not. Study group consisted of 428 university students (277 female; 171 male). To analyze the data, Pearson Product moment correlation, stepwise linear multiple regression methods and independent sample t test were used. The results showed that there was a negative significant relationship between self - efficacy, mature defense style and sub dimensions of tendency to fatalism. Also, a positive significant relationship between immature defense styles, neurotic defense style and sub dimensions of tendency to fatalism were observed. The result of stepwise multiple linear regression showed that the sub dimensions of fatalism tendency "lack of personal control” and "luck predicted self - efficacy, "lack of personal control” sub dimension predicted mature defense style, "luck" and "superstition" sub dimensions predicted immature defense style also, "predetermination" and "lack of personal control” sub dimensions predicted neurotic defense styles. As a result, the detection of a significant relation between tendency to fatalism and self - efficacy and defense mechanisms, also, those variables predicted by fatalism tendency, the differentiation by gender of fatalism tendency is important to show that individual and social factors mutually influence each other.
\end{abstract}

Keywords: Tendency of fatalism, self-efficacy, defense styles 


\section{Giriş}

Kadercilik psikoloji, sosyoloji, ilahiyat, antropoloji vb. birçok disiplinde ele alınan önemli kavramlardan biridir. Genel olarak kadercilik yaşamda olan / olacak olan her şeyin önceden doğaüstü bir gücün iradesiyle belirlendiği; önceden belirlenmiş olan alınyazısının değiştirilemeyeceği, çaba harcayarak bu belirlenmişliğin dışına çıkılamayacağını vurgulayan ve bu durumun hayatın kaçınılmaz bir gerçeği olarak kabul edilmesi gerektiği, kişinin kendi yaşamını kontrol edemeyeceği, insanın seçim yapma şansının olmadığı inancı olarak tanımlanmaktadır (Kasapoğlu, 2008; Rougier, 2011; Sobol-Kwapinska, 2013).

Kadercilik temelde tek tanrılı dinlerde ön plana çıkan kader inancına dayansa da tek tanrılı din inancının olmadığı toplumlarda da gözlenmektedir. Bu olgu kaderciliğin sadece dini boyutta ele alınmaması gerektiğini göstermektedir. Kaderciliğin olayları bilme, açıklama ve yorumlama konusunda insanları boyun eğme ve sorgulamamaya sevk edebilmektedir. $\mathrm{Bu}$ yönüyle de bazı istenmeyen davranışları meşrulaştırması kaderciliğin olumsuz bir kavram olarak ele alınması sonucunu beraberinde getirmektedir (Macit, 2014).

Türkiye’de kadercilik oldukça yaygın bir düşünce tarzıdır. Çarkoğlu ve Kalaycıoğlu, (2009) tarafından yapılan uluslararası karşılaştırmalı bir araştırmaya göre Türkiye’de insanların neredeyse yarısının kendi hayatlarını değiştirebilmek için yapabileceği çok az şey olduğuna inandığı ve bu bağlamda da kadercilik veya metafizik güçler tarafindan büyük ölçüde belirlenen bir hayat algısının toplumda yaygın olarak paylaşıldığı izlenimi ortaya çıkmıştır. ABD, Kanada, vb. ülkelerde ise bu oran çok daha azdır. Bu nedenle özellikle Türkiye'de kadercilik ile ilgili çalışmaların daha fazla önem arz ettiği düşünülmektedir.

Kadercilik, önceden belirlenmiş olan alın yazısının değiştirilemeyeceği, çaba harcayarak bu belirlenmişliğin dışına çıkılamayacağını (Kasapoğlu, 2008; Rougier, 2011; Sobol-Kwapinska, 2013) vurguladığı için öz yeterlik kavramı ile de ilişkili olabileceği düşünülmektedir. Öz yeterlik, insanın kendisine yönelik, belli bir bağlamda istendik sonuçları yaratabilecek gerekli davranışları başarılı bir biçimde yapabileceğine olan inancı olarak tanımlanmakta ve bireylerin ne kadar yüksek yeterlik beklentilerine sahiplerse o kadar çok aktif olup o kadar çok çaba harcayacakları belirtilmektedir (Bandura, 1977). Kadercilikte yer alan çaba harcayarak belirlenmişliğin dışına çıkamama ve öz yeterlikte yer alan yeterlik beklentisi arttıkça çaba gösterme davranışının artacağı düşüncesi birbirine zıt iki yaklaşım olarak değerlendirilebilir. 
Ege Eğitim Dergisi 2017 (18) 1: 124-145

Kadercilik Eğilimi İle Özyeterlik İnancı ve Savunma Mekanizmaları Arasındaki İlişsinin İncelenmesi

Birey, üstesinden gelemediği olaylarla baş etme mücadelesinde kendini korumak için sorumluluktan kaçınma eğilimine girebilmekte ve bu nedenle sıkı bir kaderci anlayışa sahip olabilmektedir. Kişi, kendi sorumluluğundan kaçmak için kaderciliğe sığınmakta ve baş etmekte zorlandığı olayların ve durumların sorumluluğunu doğaüstü bir güce atfederek kendini kandırma yoluna gitmektedir (Kuşat, 2000). Kaderciliğin kendi sorumluluğunu kabul etmeme ve kendini aldatma yönleri psikolojide sıklıkla kullanılan savunma mekanizmaları kavramını akla getirmektedir.

Canlıların en güçlü dürtülerinden biri de var olmak ve varlığını sürdürmektir. Dış dünyadan gelen tehlikelere karşı bütün canlılar tehlikeyi ortadan kaldırmak için kaçma veya saldırma davranışlarıyla kendilerini savunurlar. Kaçma ve savunma işlemleri sadece biyolojik tepkiler değildir. Bu tarz davranışlarda da karmaşık benlik işlemleri devreye girmektedir. Ancak benliğin savunma düzenekleri denildiğinde, dış tehlikelere karşı olan savunmalar anlaşılmamaktadır. Benliğin savunma düzenekleri, çatışma ve bunaltıya karşı kullanılan benlik işlemleridir. $\mathrm{Bu}$ düzenekler çoğunlukla bilinçdışı süreçlerdir. Bu süreçlerde birey ne tehlikenin ne de kullandığı savunmaların bilincinde değildir (Öztürk, 2002).

Savunma mekanizmaları kavramı ilk olarak Freud'un (1962) "Savunmaların Nöropsikozu" adlı çalışmasında ele alınmıştır. Freud'a (1962) göre savunma mekanizmaları kaygı ve endişe yaratan olaylara karşı bireyin ruhsal olarak kendini korumaya yönelik geliştirdiği mekanizmalardır. Başta bu mekanizmalar patolojik olarak nitelendirilse de daha sonra çatışma durumlarında bilinçdışı olarak kullanılan ve patolojik olmayan genel bir ruhsal mekanizma kategorisinin adı olarak kullanılmıştır (Cramer, 1987). Anna Freud (2004) ise savunma mekanizmalarını, egonun istenmeyen ve kaygı oluşturan durumlardan uzaklaşması işlevinin yanı sıra dürtüsel davranışlar, duygular ve içgüdüsel istekler üzerinde kontrol sahibi olmasını sağlayan psikolojik süreçler olarak tanımlamaktadır.

Anna Freud (2004) savunmaların kaynaklarına ve kaygıya bağlı olarak çeşitli şekillerde oluşabileceğini belirtmiştir. Savunmaları, süperegonun yol açtığı savunmalar, nesnel kaygının yol açtığı savunmalar, birbirine zıt isteklerin ortaya çıkarttığı çatışmalara karşı geliştirilen savunmalar ve dürtü şiddetinin yol açtığı kaygıya karşı dürtü savunması olarak sınıflandırmıştır. Buna göre bastırma, dürtü türevlerine karşı kullanılan bir savunma iken yadsıma dış uyaranlara karşı geliştirilen bir savunma mekanizmasıdır. Karşıt tepki geliştirme yadsımanın çevreden gelen etkilerle sarsılmasını önlerken ketlenme egonun dışardan gelen hoşnutsuzlukların önünü almaya yarayan kısıtlamasına işaret etmektedir. İçsel tehlikelerden korunmaya yarayan entellektüelize etmek egonun dişardan gelecek tehlikelere karşı her zaman sürdürdüğ̈ tetikte olmak ile benzerdir. 
Ege Eğitim Dergisi 2017 (18) 1: 124-145

Kadercilik Eğilimi İle Özyeterlik İnancı ve Savunma Mekanizmaları Arasındaki İlişkinin İncelenmesi

Vailant (1977) savunma mekanizmalarını hiyerarşik olarak sınıflandırmıştır. Bu sınıflandırmanın en alt basamağını narsistik ve patolojik savunmalar olarak adlandırmış ve bu savunmaların ilk gelişim dönemlerinde (genellikle beş yaşa kadar) ve ciddi psikopatolojik rahatsızlıklarda kullanıldığını belirtmiştir. İkinci basamakta yer alan olgun olmayan savunmaların (mantığa bürüme, yer değiştirme, vb.) daha çok çocuk ve ergenler ile kişilik bozuklukları ve duygu durum bozuklukları olan kişilerde yaygın olarak kullanıldıkları belirtilmektedir. Üçüncü basamakta yer alan nevrotik savunmalar (karşıt tepki geliştirme, yapma bozma, vb.), normal yetişkinlerde de kullanılmasına rağmen çoğunlukla obsesifkompulsif bozukluk ve histerik yapıdaki kişiler tarafından ya da stres altında bulunan nevrotik kişiler tarafindan kullanılmaktadır (Snarey ve Vailant, 1985). Bu tür savunmalar ruhsal gerginliği göreceli olarak düşürse bile ilişkilerde uzun vadede sorunlara neden olmaktadırlar. Dördüncü basamakta yer alan olgun savunma mekanizmaları (yüceltme, mizah, vb.) ise daha olumlu bir yapıya sahiptirler. Kökenlerini çoğunlukla olgun olmayan yani olgun olmayan savunmalardan alırlar fakat daha uyuma dönük savunmalardır. Sağlıklı bireyler tarafından kullanılan olgun savunmalar yaşam olaylarıyla baş etmeyi kolaylaştırabilmekte ve ilişkileri olumlu olarak etkileyebilmektedir (Vaillant, 1977).

Andrews, Singh ve Bond (1993) yaptıkları bir ölçek geliştirme çalışmasında Vaillant'ın (1977) hiyerarşik sınıflandırmasına uygun olarak savunma mekanizmalarının olgun olmayan (immatür), nevrotik ve olgun (matür) olarak üç boyutta toplandığını belirtmişlerdir. Olgun olmayan savunmalar; yansıtma, pasif saldırganlık, dışa vurma, yalıtma, değersizleştirme, otistik fantezi, inkar, yer değiştirme, disosiyasyon, bölünme, mantığa bürüme, bedenselleştirme olarak sıralanmaktadır. Nevrotik savunmalar; yapma-bozma, yapay özgecilik, idealleştirme, karşıt tepki geliştirme mekanizmalarıdır. Olgun savunmalar başlığı altında ise yüceltme, mizah, beklenti ve baskılama mekanizmaları yer almaktadır (Andrews, Singh ve Bond, 1993).

Savunma mekanizmalarının kadercilik eğilimi ile bağlantılı olduğu düşünülmektedir. Çünkü savunma mekanizmaları, klasik psikoanalizde yer alan Psişik Determinizm ilkesinin bir görüngüsü olarak kadercilik eğiliminin ileri sürdüğü "her şey benim dışımda oluşuyor" anlayışı ile paraleldir. Yani savunma mekanizmaları da kadercilik de insanın kendisi dışındaki etkenler tarafından belirlenmiş olduğu fikrina dayanmaktadır. Bireyin kendisine rahatsızlık veren içsel ve dışsal uyarıcılara karşı geliştirdiği savunma mekanizmaları ve kişiyi gerçekliği çarpıtarak sorumluluk almaktan alıkoyan kadercilik eğilimi bireylerin zorlandıkları durumlarla baş etmek için gerçeği çarpıtma yoluna gitmeleri yönüyle benzerdir. Bu nedenle kaderciliğin bir savunma mekanizması olarak ele alındığına (Brittle ve Cosgrove, 2006) ve 
Ege Eğitim Dergisi 2017 (18) 1: 124-145

Kadercilik Eğilimi İle Özyeterlik İnancı ve Savunma Mekanizmaları Arasındaki İlişkinin İncelenmesi

kaderciliğin mantığa bürüme, çarpıtma, yansıtma, yadsıma gibi savunma mekanizmalarıyla açıklandığına da rastlanmaktadır (Kasapoğlu, 2008).

Dağ (1999) yaptı̆ğ bir çalışmada paranormal inançlar (doğaüstü güçler, telepati vb. şeylere inanma), kontrol odağı ve psikiyatrik belirtiler arasında anlamlı bir ilişki olduğu sonucuna ulaşmıştır. Dış denetimli olanlar iç denetimlilere göre, paranormal inançları olanlar, paranormal inançları olmayanlara oranla daha çok belirti bildirmişlerdir. Aynı çalışmada cinsiyet değişkenine göre de farklılık olduğu ve kadınların erkeklere oranla batıl inançlar sahip olma konusunda daha yüksek puanlar aldıkları saptanmıştır.

Toplumsallaşma sürecinde kadınlara kendi hayatlarının kontrolünün kendi ellerinde olmadığı, ne yaparlarsa yapsınlar, var olan kalıp yargıları aşamayacakları, kaderlerine boyun eğmeleri gerektiği toplum tarafından öğretilmektedir. $\mathrm{Bu}$ nedenle kadınların "belirlenmişlikle" beslenen negatif kaderciliklerinin daha çok hayatları üzerinde kontrol sahibi olmalarına izin verilmemesi sonucu geliştiğini söylemek mümkündür. Kadınların kadercilik eğilimlerinin yüksek oluşu, kadınlar hakkında sürekli olarak onların katılmadıkları kararların verilmesi ve edilgen bırakılmalarının kadınların durumlarını kader olarak algılamalarının neden olabileceği belirtilmektedir (Bilican Gökkaya, 2015; Yaşar, 2007).

Diğer taraftan ruh sağlığı alanında yardım arama davranışının da kaderci yaklaşımlardan etkilendiğini gözlemlemek mümkündür. Kaderci eğilimlerin bir sonucu olarak cinci, üfürükçü, muskacı vb. olsun veya medyum, astrolog vb. çağdaş versiyonları olsun ruh sağlığı alanında herhangi bir eğitim almamış kişilere ruh sağlığı alanında yardım almak için başvuran veya bu kişiler tarafından suiistimal edilen oldukça fazla sayıda birey olduğu bilinmektedir. Klinik örneklemde ise bu tarz kişilere başvurma oranının \% 80’i bulduğu bildirilmektedir (Özden Vedi, Yargıç ve Kaya, 1997). Yaşamdaki pozisyonlarını talih, kader vb. faktörlere bağlayan ve buna göre davranan insanlar oluşturulan toplumların bilimsel gelişim, ekonomik refah ve siyasal yapıdaki özgürleşme kriterlerine göre oldukça alt düzeylerde kaldıkları görülmektedir (Masalcı - Burçak, 2012).

Savunma mekanizmaları psikoanalitik teoriye gore bilinçdışında işleyen ve egonun yaşadığı kaygıyı azaltmaya dönük çabalardır. En temel özellikleri bilindışı süreçler olmaları ve bireyin farkındalık alanının dışında olmalarıdır (Freud, 1962). Bu yönüyle öğrenilmiş davranışlar değildir. Kadercilik eğilimi ise öğrenilmiş davranışlardır. Özyeterlik inancı ise bireyin bir işi yapıp yapamayacağına ilişkin inancıdır (Bandura, 1977). Öğrenilmiş bir davranış olarak kadercilik eğiliminden öğrenilmemiş, bilinçdışı süreçler olan savunma mekanizmaları ve yine öğrenilmiş bir davranış olarak özyeterlik algısının yordanıp yordanamayacağı bu araştırmanın çıkış noktası ve temel kurgusudur. Kişinin yaşamı üzerinde 
herhangi bir kontrolünün olmadığg ve yaşamıyla ilgili konularda doğaüstü güçlerin, şans ve batıl inanç gibi faktörlerin etkili olduğunu düşünmesinin yani kadercilik eğiliminin kişinin kullandığı savunma mekanizmalarıyla da ilişkili olabileceği, ayrıca kadercilik eğiliminin bireyin özyeterlik algısını da olumsuz yönde etkileyebileceği düşünülmektedir. Bu nedenle bu çalışmanın amacı kadercilik eğiliminin özyeterlik algısı ve savunma biçimleri (olgun olmayan, olgun ve nevrotik) ile ilişkili olup olmadığı, bireylerin kadercilik eğilimlerinin özyeterlik algılarını ve savunma biçimlerini yordayıp yordamadığı belirlemek ve kadercilik eğiliminin cinsiyete gore farklılaşıp farklılaşmadığını test etmektir.

\section{Yöntem}

\section{Araştırmanın Modeli}

Araştırma, betimsel nitelikte ilişkisel tarama modeline dayanmaktadır. İlişkisel tarama modelleri iki ya da daha çok değişken arasında birlikte değişim varlığını belirlemeyi amaçlar (Karasar, 1984).

\section{Çalışma Grubu}

Bu araştırmanın çalışma grubunu 2015 - 2016 eğitim öğretim yılında Akdeniz Bölgesindeki bir üniversitede eğitim gören ve pedagojik formasyon eğitimi alan 428 öğrenci oluşturmaktadır. Çalışma grubuna demografik değişkenlere ilişkin bilgileri Tablo 1'de verilmiştir:

Tablo 1. Çalışma Grubuna Ilişkin Betimsel İstatistikler

\begin{tabular}{llcl}
\hline Değişken & Gruplar & Frekans & Yüzde (\%) \\
Cinsiyet & Kız & 277 & \\
& Erkek & 151 & 53,1 \\
En Uzun süre kalınan & Köy-Kasaba & 47 & 11,0 \\
Yerleşim Birimi & Şehir & 104 & 24,3 \\
& Büyükşehir & 146 & 34,1 \\
Sosyo-ekonomik & Düşük & 131 & 30,6 \\
düzey algıs1 & Orta & 296 & 10,7 \\
& Yüksek & 87 & 68,9 \\
& 1 & 64 & 20,3 \\
Sinıf düzeyi & 2 & 71 & 15,0 \\
& 4 & 161 & 16,6 \\
& Mezun & 132 & 37,6 \\
\hline
\end{tabular}

\section{Veri Toplama Araçları}

Kadercilik Eğilimi Ölçeği. Bu çalışmada katılımcıların kadercilik eğilimlerini belirlemek amacıyla Kaya ve Bozkur (2015) tarafından geliştirilen Kadercilik Eğilimi Ölçeği 
kullanılmıştır. Ölçeğin yapı geçerliliği için yapılan çalışmada açımlayıcı faktör analizinden yararlanılmış ve ölçeğin Önceden Belirlenmişlik, Kişisel Kontrol, Batıl İnanç ve Şans faktörleri olmak üzere dört faktörden oluştuğu belirlenmiştir. Kadercilik Eğilimi Ölçeği ile Dağ (2002) tarafından geliştirilen Kontrol Odağı Ölçeği arasında yapılan ölçüt bağıntılı geçerlik çalışmasında kadercilik eğilimi arttıkça dış kontrolün arttığı gözlenmiştir.

Yirmi dört maddeden oluşan ölçekte “Önceden Belirlenmişlik" boyutundan alınabilecek maksimum puan 40 minimum puan 8'dir. Bu boyuttan alınan yüksek puan önceden her şeyin önceden belirlenmiş olduğuna yönelik algının yüksek olduğunu göstermektedir. Kişisel kontrol boyutundan alınabilecek maksimum puan 30, minimum puan ise 6'dır. $\mathrm{Bu}$ boyuttan alınan yüksek puan kişisel kontrol algısının zayıf olduğunu göstermektedir. Ölçeğin üçüncü Alt boyutu "Batıl İnanç” boyutudur. Bu boyutta alınabilecek maksimum puan 30 minimum puan 6' dır. Bu boyuttan alınan yüksek puan batıl inançlara inanma eğilimin yüksek olduğunu göstermektedir. Dördüncü alt boyut ise "Şans" alt boyutudur. $\mathrm{Bu}$ boyuttan alınabilecek maksimum puan 20, minimum puan 4'tür. $\mathrm{Bu}$ alt boyuttan alınan yüksek puan şans faktörüne inanma eğiliminin yüksek olduğunu göstermektedir. Sonuç olarak tüm alt boyutlar kadercilik eğilimini ölçmektedir. Ölçekten alınabilecek maksimum puan 120 minimum puan ise 24'tür. Ölçeğin tüm alt boyutlarından alınan puanlar toplanarak toplam kadercilik eğilimi puanı elde edilmektedir. Puan yükseldikçe kadercilik eğilimi yükselmektedir. Kadercilik Eğilimi ölçeğinin Cronbach Alfa katsayıları sırasıyla tüm ölçek için .86, önceden belirlenmişlik alt boyutu için .86, kişisel kontrol alt boyutu için .78, Batıl inanç alt boyutu için .81 ve Şans alt boyutu için ise .71 olarak bulunmuştur. Ölçeğin test tekrar test güvenirliği .72'dir. Bu çalışmada ise ölçeğin Cronbach Alfa katsayıları sırasıyla tüm ölçek için .86, önceden belirlenmişlik alt boyutu için .85, kişisel kontrol alt boyutu için .73, Batıl inanç alt boyutu için .79 ve Şans alt boyutu için ise .67 olarak hesaplanmıştır.

Savunma Biçimleri Testi-40 (SBT-40). Bu çalışmada Andrews ve diğ. (1993) tarafından geliştirilmiş olan ve Yılmaz, Gençöz ve Ak (2007) tarafından Türkçeye uyarlanan Savunma Biçimleri Testi-40 Kullanılmıştır. Kırk maddeden oluşan Savunma Biçimleri Testi (SBT-40) bilinçdışı olarak kullanılan savunma mekanizmalarının bilinç düzeyindeki yansımalarını deneysel olarak değerlendiren toplam 40 ölçek maddesi ve 20 savunma biçiminden oluşan bir ölçme aracıdır. Ölçekte her bir madde 1 (bana hiç uygun değil) ile 9 (bana çok uygun) arasında puanlanmaktadır. Olgun Olmayan (İmmatur) savunmalar; dışa vurma, yalıtma, yansıtma, pasif saldırganlık, değersizleştirme, otistik fantezi, inkar, yer değiştirme, disosiyasyon, bölünme, mantıksallaştırma, bedenselleştirme savunmalarından oluşmaktadır. 
Nevrotik savunmalar; yapma-bozma, yapay özgecilik, idealleştirme, karşıt tepki geliştirme savunma mekanizmalarını içermektedir. Olgun yani (matur) savunmalar ise yüceltme, mizah, beklenti ve baskılama savunmalarından oluşmaktadır. Olgun, Nevrotik ve Olgun Olmayan Savunma Biçimleri iç tutarlık katsayıları sırasıyla, .70, .61 ve .83 olarak bildirilmiştir. Test tekrar test korelasyon katsayısı Olgun, Nevrotik ve Olgun olmayan savunmalar için sırasıyla, .75, .88 ve .86'dır. Bu çalışmada ise iç tutarlık katsayıları Olgun, Nevrotik ve Olgun olmayan savunmalar için sırasıyla, .64, .55 ve .74 olarak hesaplanmıştır.

Genel Öz yeterlik Ölçeği (GÖYÖ). Schwarzer ve Jerusalem (1995) tarafindan geliştirilen ve Aypay (2010) tarafından Türkçe'ye uyarlanan bu ölçek katılımcıların özyeterlik inançlarını belirlemek için kullanılmıştır. İki faktörden oluşan bu ölçeğin ilk faktörü çaba göstermeyi ve dirençli olmayı vurgulayan "çaba ve direnç" faktörü, ikincisi ise zorluklarla baş etmede yetenek ve kendine güveni vurgulayan “yetenek ve güven” faktörüdür. Ölçeğin güvenirliği ile ilgili olarak alfa iç tutarlılık katsayısı hesaplanmış ve test-tekrar test korelasyonlarına bakılmıştır. Birinci alt boyutun alfa iç tutarlılık katsayıs1.79, ikinci alt boyutun .63 olarak hesaplanmıştır. Ölçeğin tamamı için hesaplanan alfa iç tutarlılık katsayısı ise .83'tür. Ölçeğin test tekrar test güvenirliği için hesaplanan korelasyon katsayısı .80’dir. GÖYÖ’deki tüm maddeler düz puanlanmakta ve ölçekten 10 ile 40 arasında puan alınabilmektedir. Yüksek puan genel öz yeterliğin yüksek olduğunu göstermektedir (Aypay, 2010). Bu çalışmada ise ölçeğin toplamı için alfa içtutarlılık sayısı .87 olarak hesaplanmıştır. Birinci alt boyutun alfa iç tutarlılık katsayısı .82, ikinci alt boyutun alfa iç tutarlılık katsayısı ise .72 olarak hesaplanmıştır.

Kişisel bilgi formu. Araştırmacılar tarafından hazırlanan kişisel bilgi formu; çeşitli demografik bilgileri elde etmek için hazırlanmıştır. $\mathrm{Bu}$ form; cinsiyet, eğitim durumu, algılanan sosyo-ekonomik düzey ve kişinin hayatının çoğunu geçirdiği yerleşim birimini belirlemeye yönelik sorulardan oluşmaktadır.

\section{Verilerin Analizi}

Savunma Biçimleri, Genel Özyeterlik ve Kadercilik Eğilimi arasındaki ilişkinin analizi 'Pearson Momentler Çarpım Korelasyon Katsayısı' tekniği kullanılarak yapılmıştır. Kadercilik eğiliminin alt boyutlarının genel özyeterlik, olgun olmayan, olgun ve nevrotik savunma biçimlerini açıklama gücünü belirlemek için ise aşamalı çoklu doğrusal regresyon analizinden yararlanılmıştır. Analizlerde SPSS 22.0 paket programı kullanılmıştır. 


\section{Bulgular}

Katılımcıların, Genel Özyeterlik, Nevrotik, Olgun ve Olgun olmayan Savunmalar ile Kadercilik Eğiliminin alt boyutları olan Belirlenmişlik, Kişisel Kontrol, Batıl İnanç ve Şans arasındaki ilişki Pearson momentler çarpımı korelasyon katsayısı ile incelenmiş ve elde edilen sonuçlar Tablo 2'de verilmiştir.

Tablo 2. Katılımcıların, Genel Özyeterlik, Savunma Mekanizmaları ile Kadercilik Eğilimi ve Kadercilik Ĕgiliminin Alt Boyutları Arasındaki Korelasyon

\begin{tabular}{lcclcl}
\hline $\begin{array}{l}\text { Kadercilik } \\
\text { Eğilimi ve Alt }\end{array}$ & Özyeterlik & $\begin{array}{c}\text { Nevrotik } \\
\text { İnanc1 }\end{array}$ & $\begin{array}{c}\text { Olgun } \\
\text { Savunmalar }\end{array}$ & $\begin{array}{c}\text { Olgun } \\
\text { Savunmalar }\end{array}$ & $\begin{array}{c}\text { Olmayan } \\
\text { Savunmalar }\end{array}$ \\
\hline $\begin{array}{l}\text { Kadercilik } \\
\text { Eğilimi }\end{array}$ & $\mathrm{r}$ & $-.238^{* *}$ & $.243^{* *}$ & $-.222^{* *}$ & .073 \\
Belirlenmişlik & $\mathrm{r}$ & $-.119^{*}$ & $.149^{* *}$ & $-.116^{*}$ & $.143^{* *}$ \\
Kişisel Kontrol & $\mathrm{r}$ & $-.304^{* *}$ & -.092 & $-.282^{* *}$ & .092 \\
Bat1l İnanç & $\mathrm{r}$ & $-.118^{*}$ & $.099^{*}$ & $-.133^{* *}$ & $.232^{* *}$ \\
Şans & $\mathrm{r}$ & $-.179^{* *}$ & .024 & $-.150^{* *}$ & $.266^{* *}$ \\
\hline $\mathrm{n}=428,{ }^{*} p<.05, * * p<.01$ & & & &
\end{tabular}

Tablo 2 incelendiğinde katılımcıların Genel Özyeterlik Algıları ile Kadercilik Eğilimi Ölçeğinin Önceden Belirlenmişlik, Kişisel Kontrol, Şans ve Batıl İnançalt boyutları arasında negatif yönde anlamlı bir ilişki olduğu görülmektedir $\left(r=-.119^{*}\right.$, $-.304^{* *}$, $-.118^{*}$ ve $\left.-.179^{* *}\right)$. Kadercilik Eğilimi toplam puanıyla katılımcıların Genel Özyeterlik Algıları arasında da negatif yönde ve anlamlı bir ilişki vardır $\left(r=-.238^{*}\right)$. Katılımcıların Nevrotik Savunma Biçimleri ve kadercilik eğilimi ölçeğinin Önceden Belirlenmişlik ve Batıl İnanç alt boyutları arasında pozitif yönde ve anlamlı bir ilişki olduğu gözlenmektedir $\left(r=.149^{* *}\right.$ ve $\left..099^{*}\right)$. Katılımcıların Nevrotik Savunma Biçimleri Kadercilik Eğilimi Ölçeğinin toplam puanıyla ise pozitif yönde ve anlamlı bir korelasyona sahiptir $\left(r=.243^{* *}\right)$. Katılımcıların Nevrotik Savunma Biçimleri İle Kişisel Kontrol ve Şans alt boyutları arasındaki ilişki ise istatistiksel olarak anlamlı değildir. Katılımcıların Olgun Savunma Biçimleri ile Kadercilik Eğilimi Ölçeğinin Önceden Belirlenmişlik, Kişisel Kontrol, Şans ve Batıl İnanç alt boyutları arasında negatif yönde anlamlı bir ilişki olduğu görülmektedir $\left(r=-.116,^{*}-.282^{* *},-.133^{* *}\right.$ ve $\left.-.150^{* *}\right)$. Katılımcıların olgun Savunma Biçimleri ile Kadercilik Eğilimi Ölçeğinin toplam puanı arasında ise negatif yönde ve anlamlı bir ilişki vardır $\left(r=-222^{* *}\right)$. Katılımcıların olgun omayan Savunma Biçimleri ve Kadercilik Eğilimi Ölçeğinin Önceden Belirlenmişlik, Şans ve Batıl İnanç alt boyutları arasında pozitif yönde anlamlı bir ilişki olduğu görülmektedir ( $r=$ 
Ege Eğitim Dergisi 2017 (18) 1: 124-145

Kadercilik Eğilimi İle Özyeterlik İnancı ve Savunma Mekanizmaları Arasındaki İlişkinin İncelenmesi

$.143^{* *}, .232^{* *}$ ve $.266^{* *}$ ). Katılımcıların Olgun Olmayan Savunma Biçimleri ve Kişisel Kontrol alt boyutu arasındaki ilişki ise istatistiksel olarak anlamlı değildir.

Katılımcıların, kadercilik eğiliminin alt boyutları olan önceden belirlenmişlik, kişisel kontrol eksikliği, şans ve batıl inanç boyutlarının genel özyeterlik düzeyini açıklama gücü aşamalı çoklu doğrusal regresyon analizi ile incelenmiş ve elde edilen sonuçlar Tablo 3'te verilmiştir.

Tablo 3. Kadercilik Eğiliminin Genel Özyeterlik Inancı Düzeyini Açıklama Gücü

\begin{tabular}{|c|c|c|c|c|c|c|c|c|c|c|}
\hline Yordanan & Model & Yordayıcı & B & Sh & $\beta$ & $\mathrm{t}$ & F & $\mathrm{p}$ & $\mathrm{R}$ & $\mathrm{R}^{2}$ \\
\hline Değgişken & & Değişkenler & & & & & & & & \\
\hline Genel & & Sabit & 36,157 & .843 & & 42,866 & & & & \\
\hline Özyeterlik & 1 & Kişisel & -.434 & .066 & - & 6,585 & 43,366 & .000 & & .092 \\
\hline \multirow[t]{3}{*}{ İnanc1 } & & Kontrol & & & .304 & & & & .304 & \\
\hline & 2 & Şans & -.182 & .075 & - & 2,423 & 24,864 & .000 & .324 & .105 \\
\hline & & & & & .114 & & & & & \\
\hline
\end{tabular}

Toplam: $\mathrm{R}^{2}=, 105, p<.05$

Tabloda aşamalı çoklu doğrusal regresyon analizinin iki aşamada tamamlandığı ve varyansa katkıları bakımından Kadercilik eğiliminin Kişisel Kontrol ve Şans boyutlarının Genel Öz Yeterlik İnancının anlamlı yordayıcıları olduğu görülmektedir. Analiz aşamasında ilk sırada bulunan "Kişisel Kontrol” değişkeninin ilgili $\mathrm{R}^{2}$ değerleri incelendiğinde katılımcıların Genel Özyeterlik İnancı puanlarında gözlenen toplam varyansın \% 9,2'sini açıkladığı görülmektedir. "Kişisel Kontrol” değişkeninin varyansa olan bu katkısı anlamlıdır. $\left(R^{2}=.092, p<.01\right)$. İkinci aşamada yordama işlemine katılımcıların Kadercilik Eğilimi ölçeğinin alt ölçeği olan "Şans”'ın dahil edilmesiyle toplam varyansın \% 10,5'e yükseldiği görülmektedir. "Şans" değişkeninin varyansa olan bu katkısı anlamlıdır. $\left(R^{2}=.105, p<.01\right)$. Kadercilik eğiliminin Önceden Belirlenmişlik ve Batıl inanç boyutları ise anlamlı yordayıcılar değildir.

Katılımcıların, kadercilik eğiliminin alt boyutları olan Önceden Belirlenmişlik, Kişisel Kontrol Eksikliği, Şans ve Batıl İnanç boyutlarının Olgun Olmayan savunma mekanizmalarını kullanama düzeyini açıklama gücü aşamalı çoklu doğrusal regresyon analizi ile incelenmiş ve elde edilen sonuçlar Tablo 4'te verilmiştir. 
Ege Eğitim Dergisi 2017 (18) 1: 124-145

Kadercilik Eğilimi İle Özyeterlik İnancı ve Savunma Mekanizmaları Arasındaki İlişkinin İncelenmesi

Tablo 4. Kadercilik Eğiliminin Olgun Olmayan Savunma Biçimlerini Açıklama Gücü

\begin{tabular}{|c|c|c|c|c|c|c|c|c|c|c|}
\hline Yordanan & Model & Yordayıc1 & B & Sh & $\beta$ & $\mathrm{t}$ & $\mathrm{F}$ & $\mathrm{p}$ & $\mathrm{R}$ & $\mathrm{R}^{2}$ \\
\hline Değişken & & Değişkenler & & & & & & & & \\
\hline \multirow{4}{*}{$\begin{array}{l}\text { Olgun } \\
\text { Olmayan } \\
\text { Savunmalar }\end{array}$} & & Sabit & 79,071 & 4,084 & & 19,361 & & & & \\
\hline & & Şans & 1,995 & .350 & .270 & 5,695 & 32,413 & .00 & & .073 \\
\hline & 1 & & & & & & & & .270 & \\
\hline & 2 & Bat1l İnanç & .617 & .275 & .126 & 2,244 & 19,090 & .00 & .290 & .084 \\
\hline
\end{tabular}

Toplam: $\mathrm{R}^{2}=.084, p<.05$

Tabloda aşamalı çoklu doğrusal regresyon analizinin iki aşamada tamamlandığı ve varyansa katkıları bakımından Kadercilik eğiliminin Şans ve Batıl İnanç boyutlarının Olgun Olmayan savunma biçimlerinin anlamlı yordayıcıları olduğu görülmektedir. Analiz aşamasında ilk sırada bulunan "Şans" değişkeninin ilgili $\mathrm{R}^{2}$ değerleri incelendiğinde katılımcıların Olgun Olmayan Savunma Biçimleri puanlarında gözlenen toplam varyansın \% 7,3’ünü açıkladığı görülmektedir. "Kişisel Kontrol” değişkeninin varyansa olan bu katkısı anlamlıdır. $\left(R^{2}=\right.$ $.073, p<.05)$. İkinci aşamada yordama işlemine katılımcıların Kadercilik Eğilimi ölçeğinin alt ölçeği olan "Batıl İnanç”ın dahil edilmesiyle toplam varyansın \% 8,4'e yükseldiği görülmektedir. "Batıl İnanç” değişkeninin varyansa olan bu katkısı anlamlıdır. $\left[R^{2}=.084, p<\right.$ .05]. Kadercilik eğiliminin Önceden Belirlenmişlik ve kişisel kontrol boyutları ise anlamlı yordayıc1lar değildir.

Tablo 5. Kadercilik Eğiliminin Olgun Savunma Biçimlerini Açıklama Gücü

\begin{tabular}{|c|c|c|c|c|c|c|c|c|c|c|}
\hline Yordanan & Model & Yordayıc & B & Sh & $\beta$ & $\mathrm{t}$ & $\mathrm{F}$ & $\mathrm{p}$ & $\mathrm{R}$ & $\overline{\mathrm{R}^{2}}$ \\
\hline Değişken & & Değişkenler & & & & & & & & \\
\hline Olgun & 1 & Sabit & 55,098 & 1,639 & & 33,620 & 36,680 & .000 & .282 & .079 \\
\hline \multirow[t]{2}{*}{ Savunmalar } & & Kişisel &,- 775 & .128 &,- 282 & $-6,056$ & & & & \\
\hline & & Kontrol & & & & & & & & \\
\hline
\end{tabular}

Toplam: $R^{2}=.079, p<.05$

Tabloda aşamalı çoklu doğrusal regresyon analizinin tek aşamada tamamlandığı ve Kadercilik eğiliminin Kişisel Kontrol alt boyutunun Olgun Savunma Biçimlerinin anlamlı bir yordayıcısı olduğu görülmektedir. "Kişisel Kontrol” değişkeninin ilgili $\mathrm{R}^{2}$ değerleri incelendiğinde katılımcıların Olgun Savunma Biçimleri puanlarında gözlenen toplam varyansın \% 7,9'unu açıkladığı görülmektedir. "Kişisel Kontrol” değişkeninin varyansa olan bu katkısı anlamlıdır. 
$\left[F_{\text {reg }}=36.620, p<.005\right]$. Kadercilik Eğiliminin Önceden Belirlenmişlik, Şans ve Batıl İnanç boyutları ise Olgun Savunma Biçimlerinin anlamlı yordayıcıları değildir.

Tablo 6. Kadercilik Eğiliminin Nevrotik Savunma Biçimlerini Açıklama Gücü

\begin{tabular}{|c|c|c|c|c|c|c|c|c|c|c|}
\hline Yordanan & Model & Yordayıc1 & B & Sh & $\beta$ & $\mathrm{t}$ & $\mathrm{F}$ & $\mathrm{p}$ & $\mathrm{R}$ & $\mathrm{R}^{2}$ \\
\hline Değişken & & Değişkenler & & & & & & & & \\
\hline Nevrotik & & Sabit & 37,259 & 1,680 & & 22,178 & & & & \\
\hline \multirow[t]{4}{*}{ Savunmalar } & & Önceden & .216 & .069 & .149 & 3,112 & 9,684 & .002 & .149 & .022 \\
\hline & 1 & Belirlenmişlik & & & & & & & & \\
\hline & 2 & Kişisel & -.328 & .130 & .121 & $-2,513$ & 8,059 & .012 & .191 & .037 \\
\hline & & Kontrol & & & & & & & & \\
\hline
\end{tabular}

Toplam: $\mathrm{R}^{2}=.037, \mathrm{p}<.05$

Tablo 6'da görüldüğü gibi katılımcıların Nevrotik Savunma Biçimlerinin yordanmasına ilişkin aşamalı regresyon analizi sonuçlarına göre iki farklı regresyon modeli ortaya çıkmıştır. Analiz aşamasında ilk sırada bulunan “Önceden Belirlenmişlik” değişkeninin ilgili $\mathrm{R}^{2}$ değerleri incelendiğinde katılımcıların nevrotik savunma biçimleri puanlarında gözlenen toplam varyansın \% 2,2'sini açıkladığg görülmektedir. Katılımcıların “Önceden Belirlenmişlik” değişkeninin varyansa olan bu katkısı anlamlıdır. $\left(R^{2}=.022, p<.05\right)$. İkinci aşamada yordama işlemine katılımcıların Kadercilik Eğilimi ölçeğinin alt ölçeği olan "Kişisel Kontrol’ün dahil edilmesiyle toplam varyansın \% 3,7'ye yükseldiği görülmektedir $\left(R^{2}=.037\right.$, $\mathrm{p}<.05)$.

Çalışma kapsamında katılımcıların kadercilik eğilimleri cinsiyetlerine göre de incelenmiştir. Katılımcıların kadercilik eğilimi puanlarının cinsiyete göre anlamlı bir farklılık gösterip göstermediğini belirlemek için bağımsız örneklemler için t testi yapılmıştır. Uygulanan bağımsız örneklemler için t testi sonuçları tablo 7 de gösterilmiştir.

Tablo 7. Cinsiyet Değişkenine Göre Katılımcıların Kadercilik Ĕgilimi Puanlarına İlişkin T Testi Sonuçlart

\begin{tabular}{lllllll}
\hline Cinsiyet & $\mathrm{N}$ & $\overline{\mathrm{X}}$ & $\mathrm{SS}$ & $\mathrm{Sd}$ & $\mathrm{t}$ & $\mathrm{P}$ \\
\hline Kadın & 277 & 60,93 & 12,81 & 426 & 3,189 &, 006 \\
Erkek & 151 & 56,47 & 15,53 & & &
\end{tabular}

Cinsiyet değişkenine göre katılımcıların kadercilik eğilimi puanlarına ilişkin t testi sonuçları tabloda görülmektedir. Yapılan analiz sonucunda katılımcıların cinsiyet değişkenine göre kadercilik eğilimleri anlamlı olarak farklılaşmaktadır $(t=3.189 ; p<.05)$. Kadın 
katılımcıların kadercilik eğilimi puanları erkek katılımcılara göre anlamlı düzeyde daha yüksektir.

\section{Tartışma, Yorum ve Sonuç}

Katılımcıların genel özyeterlk inançları kadercilik eğiliminin Önceden Belirlenmişlik, Şans ve Batıl İnanç alt boyutları arasında düşük, negatif yönde; Kişisel Kontrol alt boyutuyla ise orta düzeyde ve negatif yönde anlamlı bir ilişki olduğu görülmektedir. Bu bulguya göre özyeterlik inancı düştükçe kaderci eğilimin arttığı söylenebilir. Yapılan regresyon analizi sonucunda ise kadercilik eğiliminin kişisel kontrol eksikliği alt boyutunun genel özyeterlik inancını en fazla yordayan değişken olduğu ortaya çıkmıştır. Yine kadercilik eğiliminin şans boyutunun da genel özyeterlik inancının anlamlı bir yordayıcısı olduğu saptanmıştır. Bu sonuç araştırma beklentileriyle de uyumludur. Özyeterliği düşük olan bireylerin kişisel kontrol duygularının az olması ve hayatlarında olan şeyleri kader, şans vb. faktörlere bağlamaları anlaşılır bir durumdur. Yani kaderci yaklaşım, kişinin kendisine yönelik, belli bir bağlamda istenen sonuçları doğurabilecek gerekli davranışları başarılı bir biçimde yapabileceğine olan inancı olarak tanımlanan özyeterlik (Bandura, 1977) ile zit bir kavramdır. Literatürde kadercilik eğiliminin düşük özyeterlik inancı ile ilişkili olduğunu belirten çalışmalar bulunduğu görülmektedir. Gecas (1989) kadercilik ve dış kontrol odağının düşük özyeterlikle ilişkili olduğunu belirtirken Omu ve Reynolds (2014) yaptıkları bir çalışmada kaderci inançların özyeterliği olumsuz etkilediğini saptamışlardır. Bu bulgular araştırma sonuçlarını destekler niteliktedir.

Araştırmanın amaçlarından biri de kadercilik eğilimi ile olgun olmayan, olgun ve nevrotik savunma biçimleri arasında anlamlı bir ilişki olup olmadığı ve kadercilik eğiliminin savunma biçimlerini yordayıp yordamadığının belirlenmesidir. Yapılan analiz sonucunda Olgun Olmayan Savunma Biçimleri ve Kadercilik Eğilimi Ölçeğinin Önceden Belirlenmişlik, Şans ve Batıl İnanç alt boyutları arasında pozitif yönde anlamlı bir ilişki olduğu görülmektedir. Yani kadercilik eğilimi arttıkça olgun olmayan savunma biçimlerini kullanma oranı da artmaktadır. Yapılan regresyon analizi sonucunda ise kaderciliğin şans ve batıl inanç alt boyutlarının Olgun Olmayan Savunmaların anlamlı yordayıcıları olduğu saptanmıştır. Olgun olmayan savunmalar genellikle çocuk ve ergenler ile kişilik bozukluğu, duygu durum bozuklukları gibi psikolojik rahatsızlığı olan kişiler tarafından kullanılan savunma mekanizmalarıdır (Vailant, 1977). Büyü vb. şeylere inanma ilkel düşünce biçimlerinin günümüze yansıması olarak nitelendirilmektedir (Özden ve dĭ̆., 1997). Bu perspektiften bakıldığında olgun olmayan savunma biçimlerinin kadercilik eğiliminin şans, batıl inanç gibi 
alt boyutları tarafından yordanması bu savunmaların daha ilkel ve basit düşünme biçimlerinin ürünü olmasıyla açıklanabilir. Bu bulgu literatür ile de uyumludur. Örneğin, Dağ (1999) tarafından yapılan bir araştırmada da paranormal inançları olan dış denetimli olan kişilerin daha fazla psikolojik belirti gösterdiği sonucuna ulaşmıştır.

Olgun savunma biçimleri ise Olgun Olmayan savunma biçimlerinin tersine kadercilik eğiliminin kişisel kontrol eksikliği, Önceden Belirlenmişlik, Şans ve Batıl İnanç alt boyutları ile düşük, negatif yönde ve anlamlı bir ilişkiye sahiptir. Bu bulguya göre olgun savunma biçimlerini kulllanma oranı düştükçe kaderci eğilimin arttığı söylenebilir. Yapılan regresyon analizi sonucunda ise kişisel kontrol eksikliğinin olgun savunma biçimleirnin anlamlı bir yordayıcısı olduğu bulgusuna ulaşılmıştır. Daha çok sağlıklı bireyler tarafından kullanılan olgun savunmalar yaşam olaylarıyla başa çıkmada daha pozitif savunma biçimleri olarak değerlendirilirler (Vailant, 1977). Bu yönüyle olgun savunmaların kadercilik eğilimiyle negatif korelasyon göstermesi araştırma beklentileriyle uyumludur. Literatürde olgun savunmaların uyum bozukluğu (Erdem Işıntaş, Özgen ve Özşahin, 2008), depresyon (Aktan, 2009), alkol bağımlılı̆gı (Çağıl, 2011) gibi psikolojik problemler yaşayan kişilerde diğer savunma biçimlerine oranla daha az kullanıldığı belirtilmektedir. Bu bulgular da olgun savunmaların kadercilik eğilimi ile negatif ilişkili olmasını destekler niteliktedir.

Araştırma kapsamında kadercilik eğiliminin alt boyularıyla ilişkili olup olmadığı ve kadercilik eğilimin alt boyutları tarafından yordanıp yordanmadığı incelenen üçüncü savunma biçimi de nevrotik savunma biçimleridir. Yapılan korelasyon analizinde katılımcıların Nevrotik Savunma Biçimleri ve Kadercilik Eğilimi Ölçeğinin Önceden Belirlenmişlik ve Batıl İnanç alt boyutları arasında pozitif yönde ve anlamlı bir ilişki olduğu belirlenmiştir. Yapılan aşamalı çoklu doğrusal regresyon analizinde ise kadercilik eğiliminin "Önceden Belirlenmişlik" ve "Kişisel Kontrol” alt boyutlarının nevrotik savunmaların anlamlı yordayıcısı oldukları ortaya çıkmıştır. Nevrotik savunmalar normal yetişkinler tarafından zaman zaman kullanılsa da çoğunlukla obsesif - kompülsif veya stres altındaki nevrotik kişilikler tarafından kullanılmaktadır (Snarey ve Vailant, 1985). Yılmaz ve diğ. (2007) ise nevrotik savunmaların anksiyete ile ilişkili olduğunu belirtmişlerdir. $\mathrm{Bu}$ çerçeveden bakıldığında nevrotik savunmaları kullanan kişilerin kaygılarını azaltmak için kaderciliğin önceden belirlenmişlik ve batıl inanç boyutlarını da kullandıkları söylenebilir.

Öğrenilmiş bir davranış olarak kadercilik eğiliminden öğrenilmemiş, bilinçdışı süreçler olan savunma mekanizmalarının yordanması bu çalışmanın önemli bulgularından biridir. Hem bilinçdışında olduğu kabul edilen savunma mekanizmaları hem sonradan öğrenilen kadercilik eğilimi insanın kendisi dışındaki etkenler tarafından belirlenmiş olduğu 
fikrine dayanmaktadır. Bireyin kendisine rahatsızlık veren içsel ve dışsal uyarıcılara karşı geliştirdiği savunma mekanizmaları ve kişiyi gerçekliği çarpıtarak sorumluluk almaktan alıkoyan kadercilik eğilimi bireylerin zorlandıkları durumlarla baş etmek için gerçeği çarpıtma yoluna gitmeleri yönüyle benzerdir.

Cinsiyet değişkenine göre kadercilik eğilimin farklılaşıp farklılaşmadığına yönelik yapılan t testi sonuçlarına göre puanlar arasında kadın katılımcılar lehine anlamlı bir fark olduğu görülmektedir. Kadınların daha yüksek düzeyde kaderci bir eğilim göstermesi toplumsal alandaki dezavantajlı konumlarıyla açıklanabilecek bir sonuçtur. Bu bulgu Dağ (1999) tarafından yapılan araştırmada kadınların daha yüksek düzeyde batıl inançlara veya paranormal inançlara sahip olması bulgusuyla da uyumludur. Aslan (2010) tarafından yapılan bir araştırmada kadınların batıl inanç düzeyinin erkeklere oranla daha yüksek olduğu sonucuna ulaşılmıştır. Batıl inancın da kadercilik eğiliminin bir alt boyutu olduğu düşünüldüğünde bu bulgunun da araştırmamızın bu bulgusuyla uyumlu olduğu söylenebilir.

Sonuç olarak hem sosyolojik hem dini hem de psikolojik yönü olan kadercilik eğiliminin genel özyeterlik inancı ve savunma mekanizmalarıyla ilişkisi olması ve bu değişkenleri yordaması ayrıca kadercilik eğiliminin cinsiyete göre de farklılaşması bireysel ve toplumsal faktörlerin karşılıklı olarak birbirini etkilediğini göstermesi açısından önemlidir. Bu bağlamda hem kaderciliğin toplumsal ve kültürel etkisini inceleyen araştırmaların yapılması hem de özyeterliği geliştirmenin kaderci anlayışı azaltıp azaltmadığını inceleyen deneysel araştırmaların yapılması gerektiği düşünülmektedir. Her ikisi de birer baş etme yöntemi olan kadercilik ve savunma mekanizmalarının birbirini karşılıklı olarak etkilediği düşünüldüğünde bireyler daha işlevsel baş etme yöntemleri geliştirdikçe hem olumsuz savunma biçimleri (olgun olmayan ve nevrotik) kullanma oranının düşeceği hem de kadercilik eğiliminin azalacağı düşünülmektedir. Bu nedenle psikolojik yardım mesleklerinde bulunan kişilerin bu hizmeti sunarken karşılaşılan problemlerle uygun baş etme yöntemleri üzerine yoğunlaşmaları bu sorunların azalmasına katkıda bulunabilecektir.

Araştırma bulgularına gore kadercilik eğilimi arttıkça bireylerin öz yeterlik inancı azalmaktadır. $\mathrm{Bu}$ durum psikolojik yardım süreçlerinde bireylerin kendi sorunlarının çözümünde aktif sorumluluk almalarını güçleştirebilir, kendi sorunlarını çözebileceklerine olan inançları azaldıkça yardım arama davranışları ve terapötik süreçte işbirlikçi davranışlarını azaltabilir. 


\section{Kaynakça}

Aktan, Ö. (2009). Depresyon tanısı konulmuş hastalar ile depresif şikayetleri olmayan kişilerin kullandikları savunma mekanizmaları açısından karşılaştırlması.(Yayımlanmamış yüksek lisans tezi). YÖK Ulusal Tez Merkezi veri tabanından elde edildi. (Tez no: 358105)

Andrews, G., Singh, M., \& Bond, M. (1993). The defense style questionnaire. The journal of nervous and mental disease, 181(4), 246-256 doi: 10.1097/00005053-19930400000006

Aypay, A. (2010). Genel öz yeterlik ölçeği’nin göyö Türkçe'ye uyarlama çalışması. İnönü Üniversitesi Ĕgitim Fakültesi Dergisi, 11(2), 113 -132

Bandura, A. (1977). Self-efficacy: toward a unifying theory of behavioral change. Psychological review, 84(2), 191- 215. doi: 10.1016/0146-6402(78)90002-4

Bilican - Gökkaya, V. (2015). Çaresizliği öğrenen kadın: Öğrenilmiş çaresizlik. Electronic Turkish Studies, 10(14), 53- 70.http://turkishstudies.net/ adresinden elde edildi.

Brittle, C.,ve Cosgrove, M. (2006). Unconscious motivators and situational safety belt use: literature review and results from an expert panel meeting (No. HS-810 650). https://www.nhtsa.gov/staticfiles/nti/pdf/810650.pdf adresinden elde edildi.

Cramer P. (1987) The development of defense mechanisms. Journal of Personality, 55(4), 597-614.DOI: 10.1111/j.1467-6494.1987.tb00454.x

Çağıl, D. (2011). Erkek alkol bağımlılarında savunma mekanizmalarının aleksitimi ve kişilik boyutları ile ilişkisi. (Tıpta uzmanlık Tezi).YÖK Ulusal Tez Merkezi veri tabanından elde edildi. (Tez no: 282324)

Çarkoğlu, A. ve Kalaycıŏlu, E. (2009). Türkiye'de dindarlık: uluslararası bir karşılaştırma. İstanbul: Sabanc1 Üniversitesi İstanbul Politikalar Merkezi. http://research. sabanciuniv.edu/13119/1/Rapor_Kamu-dindarl\%C4\%B1k.pdf. adresinden elde edildi.

Dağ, İ. (1999). The relationships among paranormal beliefs, locus of control and psychopathology in a Turkish college sample. Personality and Individual Differences, 26(4), 723-737.DOI: 10.1016/S0191-8869(98)00184-6 
Ege Eğitim Dergisi 2017 (18) 1: 124-145

Kadercilik Eğilimi İle Özyeterlik İnancı ve Savunma Mekanizmaları Arasındaki İlişkinin İncelenmesi

Dağ, İ. (2002). Kontrol Odağı Ölçegi (KOÖ): Ölçek geliştirme, güvenirlik ve geçerlik çalışması. Türk Psikoloji Dergisi, 17(49), 77-90.

Erdem, M., Işıntaş M., Özgen, F., ve Özşahin, A. (2008). Savunma biçimlerinin uyum bozukluğundaki rolü. Anadolu Tıbbi Araştırmalar Dergisi, 2(4),155- 159

Freud A. (2004). Ben ve savunma mekanizmalart. (Çev. Yeşim Erim), İstanbul: Metis Yayınları.

Freud, S. (1962). The Neuro-Psychoses of Defence. İçinde (J.A. Strachey. Ed.)The Standard Edition of the Complete Psychological Works of Sigmund Freud, Volume III (18931899): Early Psycho-Analytic Publications (ss. 41-61).

Gecas, V. (1989). The social psychology of self-efficacy. Annual Review of Sociology, 291316. DOI: 10.1146/annurev.so.15.080189.001451

Karasar,N.(1984). Bilimsel araştırma metodu. Ankara: Hacetepe Taş Kitapçılık.

Kasapoğlu, A. (2008). Kur'an açısından fatalizm-inkârcıların bir tutumu olarak kadercilikHikmet Yurdu 1 (1), 87-107.

Kaya, A., ve Bozkur, B. (2015). Kadercilik eğilimi ölçeğinin geliştirilmesi: geçerlik ve güvenirlik çalışması. Mersin Üniversitesi Eğitim Fakültesi Dergisi,11(3), 935-946. DOI: $10.17860 /$ efd.55137

Kuşat, A. (2000). Psikolojik bir olgu olarak kendini aldatma ve dini inançla ilişkisi. Dini Araştırmalar, 3(8), 97- 116.

Macit, M. (2014). Boyun ĕgme-başa çıkma sarkacında kadercilik: Sosyal psikolojik bir yaklaşım. İstanbul: Ötüken Neşriyat.

Masalcı - Burçak, A. D. (2012). İç denetim programının ergenlerin denetim odağl, öğrenilmiş güçlülük ve savunma mekanizmalarını kullanma biçimi üzerindeki etkisi, (Yayımlanmamış doktora tezi), YÖK Ulusal Tez Merkezi veri tabanından elde edildi. (Tez no: 313086).

Omu, O., ve Reynolds, F. (2014). Religious faith and self-efficacy among stroke patients in Kuwait: health professionals’ views. Disability and rehabilitation, 36(18), 1529-1535. 
Ege Eğitim Dergisi 2017 (18) 1: 124-145

Kadercilik Eğilimi İle Özyeterlik İnancı ve Savunma Mekanizmaları Arasındaki İlişkinin İncelenmesi

Özden, S., Vedi, F., Yargıç, İ., ve Kaya, N. (1997). Büyücü-üfürükçü-cinci ve astrolog gibi hekim olmayan kişiler ile ruh hastalıklarının ilişkilerinin çeşitli yönlerden araştırılması. Düşünen adam, 10, 17-22.

Öztürk, M. O. (2002). Ruh sağlı̆̆ı ve bozuklukları. Ankara: Nobel Tıp Kitapları.

Rougier, C. (2011). Cultural values religiosity and spirituality as predictors of professional psychological help- seeking behavior of black adults in the united states. Unpublished doctoral disseratation. New York: Columbia University, School of Arts and Sciences.http://hdl.handle.net/10022/AC:P:11412 adresinden elde edildi.

Schwarzer, R. ve Jerusalem, M. (1995). Generalized self-efficacy scale. J. Weinman, S. Wright, \& M. Johnston (Eds.) içinde , Measures in health psychology: A user's portfolio. Causal and control beliefs (ss. 35-37). Windsor, UK: NFER-Nelson.

Snarey, J. R., \& Vaillant, G. E. (1985). How lower-and working-class youth become middleclass adults: The association between ego defense mechanisms and upward social mobility. Child Development, 899-910.

Sobol-Kwapinska, M. (2013). Hedonism, fatalism and 'carpe diem': Profiles of attitudes towards the present time. Time \& Society, 22 (3), 271-290. DOI: 10.1177/0961463X13487043

Vaillant, G. E. (1977). Adaptation to life. Harvard University Press.

Yaşar, M. R. (2007). Depresyonun kadınlaşması. Fırat Üniversitesi Sosyal Bilimler Dergisi, 17(2), 251-281.

Yılmaz, N., Gençöz, T., ve Ak, M. (2007). Savunma Biçimleri Testinin Psikometrik Özellikleri: Güvenilirlik ve Geçerlik Çalışması. Türk Psikiyatri Dergisi, 18(3), 244253. 


\section{Extended Abstract}

Generally fatalism is defined as a belief in which everything that happens in life is predetermined by the will of a supernatural power and in which the destiny predetermined will not change and thatwith effort nobody can exceed this predetermination. According to the fatalistic opinion, this should be regarded as an unavoidable fact of life and people cannot control their own life and do not have the chance to select (Kasapoğlu, 2008; Rougier, 2011; SobolKwapinska, 2013).

Self-efficiencyis defined as people's beliefs about themselves in which they believe they can do behaviors necessary for success that might result in the desired outcomes in a specific context. The more people have expectations for self- efficacy, the more they become active and make an effort (Bandura, 1977). The fact that the inability to go outside of predetermination by effort which situated in fatalism and the thoughts which are situated in self- efficacy increases, effort behavior would increase can be considered as two opposite approaches.

Defense mechanism is thought to be associated with tendency towards fatalism. The defense mechanisms which people develop against uncomfortable internal and external stimulatings and fatalistic tendency which detains people from taking responsibility by distorting reality is similar. Because both methods for dealing with forced situations distort the truth. Therefore, fatalism is considered both as a defense mechanism (Brittle \& Cosgrove, 2006) and explained by defense mechanisms as rationalization, distortion, reflection and denial (Kasapoğlu, 2008). It is thought that people who think they have no control over their own life and thethought of some factors such as supernatural power, luck and superstition areeffective in issues related to life, in other words, fatalistic tendency, isrelated to defensemechanisms. Also, it is supposed that fatalistic tendency affects people's beliefs of self-efficacy negatively. So, the aim of the present study is to investigate the relationship between tendency of fatalism, self efficacy and defense styles. Also, it is examined whether the dimensions of tendency of fatalism predict self efficacy and defense styles or not.

The study is a descriptive research and is based on the relational model. Relational model aims to determine the exchange of assets between two or more variables together (Karasar, 1984). Study group consisted of 428 university students (277 female; 171 male). To analyze the data, Pearson Product moment correlation, stepwise linear multiple regression methods and independent sample $\mathrm{T}$ test were administered to the data. 
Ege Eğitim Dergisi 2017 (18) 1: 124-145

Kadercilik Eğilimi İle Özyeterlik İnancı ve Savunma Mekanizmaları Arasındaki İlişkinin İncelenmesi

Fatalism tendency scale. In this study, fatalism tendency scale which was developed by Kaya and Bozkur (2015) was used to determine the fatalistic tendency of the participants. Tendency of Fatalism scale consists of 24 items.

Defense Styles test -40: In this study, Defense Styles test -40, developed by Andrews, Singh and Bond (1993) and adapted into Turkish by Yilmaz, Gençöz and Ak (2007) was used. Defense Style Questionnaire consists of 40 items. This scale is used to determine the participants’ defense styles.

General Self-Efficacy Scale: In this study, General Self-Efficacy Scalewhich was developed by ScaleSchwarzer and Jerusalem (1995) and adapted into Turkish by Aypay (2010) was used to determine the participants' self-efficacy beliefs.To analyze the data, Pearson Product moment correlation, stepwise linear multiple regression methods and independent sample $t$ test were used.

The results showed that there was a negative significant relationship between self - efficacy, mature defense style and sub dimensions of tendency to fatalism. Also, a positive significant relationship between immature defensestyles, neurotic defense style and sub dimensions of tendency to fatalism was observed. The result of stepwise multiple linear regression showed that the sub dimensions of fatalism tendency "lack of personal control" and "luck predicted self - efficacy”; "lack of personal control” sub dimension predicted mature defense style, "luck" and "superstition" sub dimensions predicted immature defense style. Also, "predetermination” and "lack of personal control” sub dimensions predicted neurotic defense styles.The result of stepwise multiple linear regression showed that the sub dimensions of fatalism tendency is "lack of personal control" and "luck predicted self - efficacy, "lack of personal control” sub dimension predicted mature defense style, "luck" and "superstition” sub dimensions predicted immature defense style. Also, "predetermination" and "lack of personal control” sub dimensions predicted neurotic defense styles. According to the independent samples t test analysis results there is a significant difference between the gender groups it was found. These results showed that women have more fatalism tendency than men.

As a result, fatalism tendency, which has both religious and sociological and psychological aspects, has relationship with general self - efficacy and defense mechanisms. And it predicts these variables. Also, differentiation by gender of fatalism tendency is important to show that individual and social factors mutually influence each other. In this context, it is important for studies which examine the social and cultural impact of fatalism.It is also thought necessary to make experimental researches to determine whether development of self-efficacyreduces 
Ege Eğitim Dergisi 2017 (18) 1: 124-145

Kadercilik Eğilimi İle Özyeterlik İnancı ve Savunma Mekanizmaları Arasındaki İlişkinin İncelenmesi

fatalism or not. When both fatalism tendency and defensemechanisms which are coping strategies and these variables influences each other, it is thought that the more people develop functional coping strategies, the more people can reduce negative defense mechanisms and fatalism tendency. 